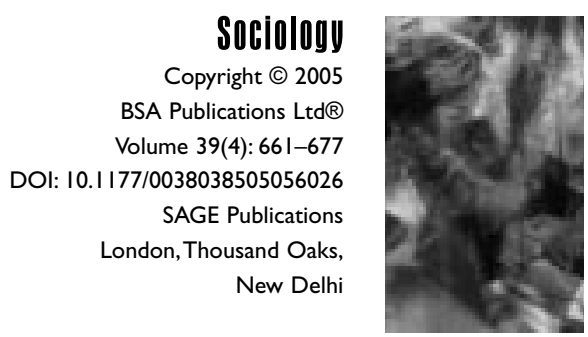

\title{
The Public and Private in C.Wright Mills's Life and Work
}

I John D. Brewer

University of Aberdeen

\begin{abstract}
Charles Wright Mills revitalized sociology's focus on the public-private distinction and this article offers a biographical reading of these writings by locating them in the turmoil of his private life. The article thus looks at the public-private distinction as it manifested in the public writings and private life of one of the major theorists of this theme. Its central argument is that we need to reposition Mills's intellectual biography by locating it spatially, for his sociological writings on this theme were heavily influenced by the 'spaces of selfhood' within which he lived and worked. This connects intellectual biography with the spatial turn in sociology. The purpose of such intellectual biography, however, is not merely to fill in the background of a sociologist's life, but to provide materials that take us to the centre of the sociological enterprise itself. It is argued that Mills's 'spaces of selfhood' are a medium into understanding his whole vision of sociology.

KEY WORDS

C. Wright Mills / intellectual biography / public-private / space
\end{abstract}

\section{Introduction}

ociology has been replete with articles discussing the public-private distinction. Originally the distinction was represented as an antinomy, becoming one of sociology's core dichotomies (Slater, 1998), but recent attention derives from the realization that it is a blurred binary. Sociologists have championed the idea that the private is social (Bailey, 2000). Fahey (1995) made the point that the family has gradations of public access (cf. McCulloch, 
1997) and Butt and Langdridge (2003) documented the extent of public access to the private more generally. Sociological analysis of the private lives of politicians has been used to challenge the notion that the personal lacks public ramifications (Holmes, 2000). Sennett (2002[1974]) refers to the 'fall of public man' as the experiences, feelings, values and interests previously restricted to the private sphere become public and virtue is no longer sovereign in public life. Ribbens-McCarthy and Edwards (2001: 772) refer not only to a constant flow between the public and private but claim that they are in a recursive relationship in which each reproduces the other. It is not just that our understanding of what is private and public is historically and culturally specific, their meaning is constituted in terms of each other. This is more than a matter of definition for sociology sees them as essentially contested with the terrain between them becoming indistinguishable as a result of their interpenetration.

In all this discussion there is rarely obeisance toward Mills's classic formulation of the distinction (2000[1959]). It was the central pillar of his work and as Denzin (1990: 16 n.7) remarked, it was Mills who virtually erased the distinction. He made two particular contributions. Mills famously staked sociology's claim to be the study of the intersection between private troubles and public issues since this located the discipline as the study of individuals within their social structural context. The intersection was presented as one of constant flow, as people's private troubles became public issues and as public issues caused people private troubles, exemplifying the mutual embeddedness of individuals and society. Secondly, Mills thought that sociologists had a responsibility to play a public role by addressing the private troubles of ordinary people. Thus, the discipline should itself be employed publicly in a manner to erode any false separation between people's private lives and the public realm. It is beside the point that this might be a utopian view of sociology, for it establishes an interesting puzzle in Mills's intellectual biography. Namely, how the public and private intersected in Mills's own life to influence his depiction of their relationship in sociology. Form (2001) recently noted this as Mills's enduring enigma, for we are no closer to understanding how Mills's private troubles affected his public work.

We address this conundrum here. The article deconstructs Mills's exploration of the public-private distinction by locating it in a new spatial approach to his intellectual biography. It argues that the collapse of the public-private distinction in his sociology reflected its collapse in his private life as a result of the tensions between the 'spaces of selfhood' in which he lived and worked. First it is necessary to understand intellectual biography as a genre and position Mills within it.

\section{Mills and Intellectual Biography}

The few autobiographies written by sociologists (as examples see Coser, 1993; Halsey, 1996; Whyte, 1994) have tended to construct a preferred reading of 
their career and offer magisterial reflections on the state of the discipline, leaving readers short on knowing much about the private selves behind their public works. However, biographical reflection in sociology takes many other forms. In methodology, post-structuralist critiques of qualitative methods in the 1980s led to the injunction that qualitative researchers be 'reflexive' and consider the range of biographical and contextual factors that situate their data. Anthologies were compiled in which researchers reflected on how their lives impacted on famous works (for example Bell and Newby, 1977), a tradition which continues (Lee-Treweek and Linkogle, 2000). Follow-up and repeat studies tend to take a pronounced biographical turn and key social scientists like Mead (Freeman, 1983), Malinowski (Geertz, 1967) and Whyte (Boelen, 1992) have had their reputations impugned by work of this kind. In social theory, several textbooks in the early 1970s addressed sociologists' private lives amidst a focus on the context to their ideas (for example Coser, 1971), and biographies appeared on major sociologists like Spencer (Peel, 1971), Durkheim (Lukes, 1972) and Weber (Bendix, 1960). While subsequent theorizing about classical sociological theory rejects an orientation on the person and thus on biographical details, this tradition has not entirely died out. Ritzer (2000[1983]) provides brief 'biographical sketches' as vignettes. The renewed interest in biography within sociology now virtually excludes a focus on the private selves of great sociologists. Post-modern deconstruction of sociology's grand narratives ends with the discipline emphasizing the biographical narratives of ordinary people analysed in very minimalist terms. The move to merge the discourses of literature and science around the genre of biography, to the point where Young described biography as the foremost human science (1988), has eschewed sociologists in favour of focusing on biographies of natural scientists for the purpose of reflecting on the development of key scientific ideas.

Herbert Spencer's equivalent of the royal butler saw his personal life exposed by two housekeepers (Anon, 1906), but as Young argued (1987), intellectual biographies normally take three forms: locating the subject's work in terms of their precursors, its social context or the subject's 'inner life'. The first we might call the history of ideas approach, the second the sociology of knowledge approach and the third, following Young, psychobiography. Previous intellectual portraits of sociologists have been of the first two kinds, although there is a move toward the third in respect to some acclaimed natural scientists (Livingstone, 2003) and psychoanalytic biographies exist (on Marx see Mazlish, 1987) offering a special take on what 'inner life' means.

Mills is an exemplar of the changing ways in which intellectual biography is constructed as a genre. It has been commonplace to position him in the social context of Cold War America (for example Binns, 1977; Casin, 1990; Clecak, 1973; Spinrad, 1966; Thompson, 1985). Themes here are Mills's political radicalism at a time of McCarthyism, and thus his disengagement from both establishment sociology and US liberal hegemony, thereby locating his attacks on liberal sociologists, like Parsons, Shils and Bell, as well as his sociological critique of US domestic and foreign policy. Mills's ideas are also popularly located 
in terms of their precursors, such as the early tradition of social reformism and critique in American sociology dating from people like Giddings (Lipset and Smelser, 1961) and Ross (Coser, 1979), the schools with which he debated (Dowd, 1964; Eldridge, 1983; Hearn, 1985; Tilman, 1984, 2003; Turner and Turner, 1990), or in the context of the professionalization of American sociology as a whole in the 1950s (Becker, 1994; Seidman, 1998). From the very beginning, people made casual observations about Mills's personal qualities and pointed prosaically to the many contradictions between his public and private selves, but systematic psychobiographies are rare.

Attempts at psychobiography reproduce the old-fashioned dichotomous view of the public-private distinction. Some explore the impact of Mills's private experiences on his public works; others locate his private troubles in terms of developments within the public sphere. Clecak (1973: 39) suggests Mills's focus on power was as a result of his own feelings of powerlessness at being a loner, but Gillam (1975) best represents work of this kind. He locates The Power Elite biographically in terms of Mills's 'traumatic experiences' during World War Two, which left a legacy of political radicalization and obsession with the military. He positions Mills's later work on the newly emerging middle class in terms of the experiences of Mills's own family in Texas, which underwent a similar transition (Gillam, 1981). But while White Collar is portrayed as strongly autobiographical, it is the experiences of Mills's maternal family on which the argument pivots; Mills's own biography was largely absent from Gillam's intellectual biography. This is not the case with Oakes and Vidich (1999). In an assessment of the Gerth-Mills relationship they locate Mills's public career in terms of his private self, the recurring motif being Mills's overbearing ambition. His goal to achieve sociological fame positions him in the academy, determining his research agenda, career moves, relationship with colleagues and blatant networking and self-promotion. He allegedly plagiarized his students' work (1999: 106-11), rode roughshod over egos, treated people instrumentally solely for their value to his career and otherwise made himself the centre of his life.

This assessment of Mills's 'inner life' had been voiced earlier by Becker (1994) who offered a different reading by reversing the focus; the private was derivative of the public. Mills's unpopularity is located in terms of the professionalization of sociology in the US that made his kind of value-oriented work inimical. Mills was also a successful popularizer whose books sold well, leading to disdain from senior colleagues who preferred professional distance. In facing a strong professional current against him, having problematic relations with all leading sociologists over theoretical, methodological and political issues, Mills's personality was unsuited to him being in the side stream yet his public rejection of colleagues only pushed him further aside (see Brewer, 2004).

As Mills's main biographer, Horowitz is recognized as offering the most substantial reading of Mills's life and career (1962, 1963, 1964, 1983). He did not shy away from discussing Mills's difficulties and was astute in merging Mills's life and work (1963: 5). There are however, three weaknesses in 
Horowitz's account. He does not make transparent the recursive nature of the public and private in Mills's personal and professional lives; he does not use his subject's life as a medium for commentary on Mills's vision for the discipline; and, above all, he follows the pattern of the genre in positioning Mills's intellectual biography temporally. In a private communication with the author, Horowitz wrote that:

Wright died at such a tender age that establishing geographical impact was beyond my ability ... I thought then, and still do, that academics (and that is, after all, what Wright remained throughout) are more creatures of university enclaves than responsive to broad places on the map.

However, a significant repositioning of Mills's intellectual biography occurs when locating it spatially, which is helpful in enabling us to address the puzzle left by current biographies which do not adequately capture the link between the public and private Mills. In so doing, we also reflect on the sociological enterprise itself, for Mills's 'spaces of selfhood' enable us to better understand his repositioning of sociology via the erosion of the public-private distinction.

\section{Space in Sociology and Biography}

Lives are lived messily, not in hermetic temporal sequences, and a spatial approach seems useful, locking biography and self into contemporary theorizations of space. The sociology of space goes back to Simmel in 1903 (Lechner, 1991), but in 1979 Giddens could reasonably protest that social science did not take space (or time) seriously (1979: 202) although he wrote this at the point when human geography (Sack, 1980), anthropology (Geertz, 1983) and social theory (Gregory and Urry, 1985) were about to do so. In sociology, Urry championed the spatialization of contemporary capitalism (1981) and the spatialization of the discipline now extends broadly. We are aware of contested spaces (Tilly, 2000), gendered spaces (Spain, 1992) and it is de rigueur that globalization has reconfigured time and space by compressing distances, with a significant impact on tourism (Urry, 2001) and the built environment (Baldry, 1999), amongst other things. The reach of space into the self, however, is not so well developed.

In his discussion of structuration theory Giddens implies a spatial understanding of identity when he refers to people's capacity to position themselves within their life path (1984: 85), but it is Goffman who makes most use of space as part of the conceptual apparatus for understanding the self. Space entered as a metaphor throughout his work, in references to 'territories of the self' and to the different regions within which the self is projected, such as 'front' and 'backstages'. Spatial imagery was not just employed rhetorically for Goffman recognized space as a process that structures normative behaviour. However, he did not address explicitly how identities are constructed spatially. It is well established in the symbolic interactionist tradition that people use identities in 
interaction in highly strategic ways to construct their biography in a manner that maximizes self benefits, but interactionists have not recognized space as part of the meaning given to the self. The philosopher Charles Taylor tackled this idea directly in his exposition of sources of the self (1989). The purpose of his analysis was to address the question of whether the self is essentially moral independent of people's desire to be so (an issue taken up more sociologically by Archer, 2000) but in the process he refers to identities as spatial constructs, since who one is depends on where one has come from and is going (1989: 29); an idea that the philosopher MacIntyre (1984: 203-4) refers to as 'the quest'. Taylor argues that people's identity is both orientated in space - the places where one is, came from and going to - and to space, in that these places are socially constructed or imagined spaces that take on a symbolic meaning. David Livingstone, a human geographer and historian of science, has extended Taylor's ideas in ways that are relevant to sociology and to Mills's intellectual biography in particular.

Livingstone (2002: 35) argues that we need to connect the private lives of scientists with their public works spatially. Documenting the biographical spaces of scientists' lives, what Livingstone calls their 'spaces of selfhood', helps us to better understand their work. Sociologically, spaces are both cultural and physical, describing social worlds that exist in time and place as physical and symbolic entities. Spaces of selfhood are those cultural and physical milieux in which people have lived and worked and whose meaning they construct as both real and symbolic places. ${ }^{1}$ Approaching an intellectual biography spatially requires us, for example, to take seriously the spaces in which our subject narrates their own life, the milieux within which their works were both written and received, and to recognize that our interpretation of the connection between their life and work is facilitated by understanding the spaces in which they were enacted. Space often put the venom into the intellectual controversies that subjects became embroiled in, since other people's reception of their work was often mediated by spatial differences. The impact of new spaces of work on the public writings of the subject, which come in the form of job moves, new colleagues, different publishers or new places of research focus and the like, can be affected by the private self's capacity to accommodate to the new relationships and networks. Sometimes a former space stays forever with the subject to mediate their reaction to the changing spaces in which their life and work are enacted. There are many instances to conjure that demonstrate that the spaces of someone's life and work help us to take the measure of that life and work.

The utility of this approach is demonstrated here by the insight it gives into Mills's exposition of the public-private distinction, which he made the hallmark of sociology. It involves reassessing the impact of his Texan upbringing and unravelling the ways in which this 'outlander' status rooted in a space of selfhood mediated the other spaces in which he lived and worked. The Texan legacy often made Mills a 'disagreeable man', to use Geertz's (1967) description of Malinowski after reading the latter's posthumous diary, but shaped positively his depiction of sociology's public role. Texas was however, both a real and a 
constructed space and it is necessary to distinguish between the genuine impacts Texas had on Mills's life and career and the way he (and his critics) used an imagined Texas as means for commentary on his life and work. A caveat must be entered however. The evidence used for this re-reading has been gleaned from his published letters. This offers imperfect access to Mills's 'inner life': the reading relies on public material not private archives; it suffers from the unknown selection biases that went into the publication of some letters rather than others; and it is limited to the self-disclosures Mills made in public. However, in research on sexuality that utilized unobtrusive measures like diaries and letters, Butt and Langdridge (2003: 483) recently argued that letters contain less 'narrative smoothing' than autobiographies and the assumed absence of a 'community of listeners' allows for a freer style of reflection. Commentators have noted that Mills's letters successfully divulge facets of his character, expose his many contradictions, and reveal his vulnerabilities and sensitivities as a sociologist (Merrifield, 2001: 292-4). They at least offer sufficient insight into Mills's 'inner life' to suggest the inadequacy of existing intellectual biographies.

\section{Wacky Waco?}

Born in Waco in 1916, Mills's panhandle roots are either derided or denuded; they become a metaphor of snobbish sarcasm or get stripped of any impact. Mills is simplistically presented therefore as either fleeing 'the intellectual desert of Texas' (Miliband, 1968: 4) to become absorbed into New York, or locked in Texas, making him uncivil (Shils, 1960). For his critics, Texas constitutes an exodus experience that frames his zealous drive (Oakes and Vidich, 1999: 91-2; Turner and Turner, 1990: 132), but even for supporters it becomes the scapegoat to explain away his disagreeable features (Miliband, 1964: 79). The idea that Texas represented a negative space in Mills's selfhood was perhaps put most succinctly by his erstwhile friend Dwight McDonald, who wrote that Texas represented in him 'the irrational', the 'rural backwoodsmanship that Mills left behind' (cited in Horowitz, 1983: 77). Acolytes used an idealization of Texas too, since it embedded imagery of Mills as a radical. Dan Wakefield's evocation of Mills has him driving into Columbia 'on his motorcycle, wearing plaid shirts, old jeans and work boots, carrying his books in a duffle bag strapped across his back' (2000: 6). Substitute horse for bike and we have the image of the feisty Texan boy, no holds barred, speaking his mind, riding into New York to take it by storm: the iconoclast in ideas as well as dress code, overturning the staid old men in grey suits and Cadillacs in sociology's establishment. Subsequent spaces of selfhood in the effete culture of Ivy League Columbia and downtown Greenwich Village are correspondingly presented therefore as either the ticket Mills uses to successfully flee from the Texan backwater or the crucifix that made him constantly suffer the legacy of his roots, 
driving him ever onwards in order to make it as a big shot, as if 'getting on' and 'getting out' were equivalent.

These arguments rest largely on social constructions of an imagined Texas that present its influence as entirely negative. There are more authentic influences that need to be marked. As a space of selfhood Texas provided the biographical context to his understanding of the public-private distinction in sociology and thus proved positive for his repositioning of sociology. However, Mills was not passive in the social construction of his biography. In later life he too often dramatized his Texan roots and deployed an imagined Texas as a strategy to mediate the personal and public troubles he experienced in other spaces of selfhood.

Mills kept a genuine affection for Texas all his life and it is possible to detect authentic influences upon him. His daughter recalls his love of the television show Rawhide (Mills and Mills, 2000: xviii), he had remembrances of his roots in his office, in the form of a toy rooster (Mills and Mills, 2000: 101) and dried sage (Mills and Mills, 2000: 124), and he retained an innocent delight in the open doors, the wide expanse of countryside and country living, which came along with satisfaction in manual labour and skilled craftsmanship. Mills was an accomplished motor mechanic. He built three homes, farmed for a year, was good at carpentry and furniture making, and baked his own bread. We see in his letters a great deal of Texan rugged independence, self-reliance and individualism as well as the psychology of the 'outlander'. There is something both real and imagined about this and in later life Mills played up to this selfconception and referred to himself as a North American aboriginal (Mills and Mills, 2000: 206). But soon after leaving Texas, Mills was writing to his parents in an outlander's terms:

My father asks, do we need anything? Does a man really need anything but what is in him? The things I need no one else can give me ... No, there is nothing that can be given to me by others. In the end a man must go to bat alone. (Mills and Mills, 2000: 40)

As others have noted (Wakefield, 2000: 14), the Texan outlander mentality gave Mills a life-long affection for the Wobblies (Industrial Workers of the World), who valued most their independence, making him an anti-joiner. As Mills wrote: 'I am no spokesman, official or unofficial, for any nation or any nationalism. I am against all prevailing nationalism' (Mills and Mills, 2000: 222). Mills was, in his own words, 'not organizable' (p. 104) and he always valued 'independence and individuality' (p. 248).

The mentality of the Texan outlander was authentic in shaping the value placed throughout his life on autonomy and self-reliance. This manifested in his private life; he wrote to an ex-lover that he 'feared anchorage' (Mills and Mills, 2000: 157). It impacted his relationships with colleagues too. 'Being his own person' made Mills incapable of working with others, and he objected to teaching because it compromised him. This outlander mentality enabled him to sustain the occupational role of loner when he found himself outside the academy. 
An ability to survive isolation and loneliness, if not a deliberate preference for it, was part of the Texan legacy and allowed Mills to ride the unpopularity of his sociological writings in the discipline. He reflected once on the 'burdens of loneliness' that accompanied his insistence on autonomy (p. 30) and recognized that 'despite my running around so much, I am very much isolated and alone' (p. 304).

Existing biographical readings concur that as a space of selfhood Texas was problematic to Mills's life in more urbane spaces of selfhood, both uptown Columbia and downtown Greenwich Village. ${ }^{2}$ However, they neglect Mills's strategic use of his roots to mediate these difficulties. For example, the wild open countryside and simple country living of his idealized youth in Texas became escape mechanisms whenever the public controversy or criticism overwhelmed him. He was aware of this even at the beginning of his career, for in a letter in 1949 he admitted how he ran around in automobiles, trailers and on bikes, to fish, ride, build homes and generally retreat from the academy - living the rugged rustic life of a Texan outlander - to avoid 'the shakes' that overcame him in writing White Collar and anticipating its negative reception (Mills and Mills, 2000: 137-8). The outlander mentality was used strategically also as a resource to rationalize his career when in other spaces of selfhood he encountered rejection and hostility or was asked to make intellectual and professional compromises for the sake of public civility with his colleagues. For example, on the breakdown in his relationship with Lazarsfeld, and in the wake of the publication of White Collar, Mills wrote to Gerth in 1952, 'to hell with professional acclaim. I lose. Nothing is worth the continual feeling that you're not your own man' (Mills and Mills, 2000: 172).

Many of his battles with colleagues, which dogged his career, were excused, sanitized and otherwise rendered emotionally harmless by means of the outlander mentality. They were people whose opinion was not worthy of sleeplessness, in part because their views as sociologists were unimportant but also, as an outlander, Mills felt he did not need the affirmation of anyone. Quite clearly he did - and his letters disclose his pain at criticism - but the Texan outlander mentality was drawn on as a resource in an attempt to emotionally neutralize it. Thus, in a letter to Gerth about Shils's objection to their Weber translations, Mills wrote reassuringly: 'you must know that nothing, nothing you can ever do will make him hate you less. You may well realize that and get along in the world without his friendship. Too bad, but inevitable' (letter in Oakes and Vidich, 1999: 29). Around the same time in letters to friends Mills said he neither expected nor wanted people's affirmation. 'Nobody is going to love me much' (Mills and Mills, 2000: 168), 'who wants to be loved?' (p. 189). Such self-reliance enabled him to cut himself off from the sociological fraternity in Columbia (Lipset and Smelser, 1961: 50) and elsewhere. He did so not just because he was rejected by them, less still because his over-bearing ambition riled or he suffered wounded pride (Gillam, 1981: 30 n. 49), but simply because he could: he could act autonomously and still survive psychologically and occupationally as a result of his Texan outlander mentality. In so doing an imagined, 
socially constructed, Texas gets drawn as a 'vocabulary of motive'. In a revealing reply to a friend in Ohio in 1953, who had written asking why Mills wrote the way he did, Mills answered:

It's a joke but a fact that my Texan grandfather has something to do with that. I am an outlander, not only regionally, but down bone deep and for good. In Orwell's phrase I am just outside the whale and always have been. (cited in Horowitz, 1983: 84)

A real and an imagined Texas helped both to create the problems he later encountered in other spaces and provided the strategy to deal with them in ways that sustained him and his work.

\section{Mills's Own Reading of His Life and Work}

It is critical to this re-reading of Mills's intellectual biography that he used the spaces in which it was enacted strategically as a way of managing the travails he experienced when the Texan outlander mentality made his life and work problematic. Mills was active in the social construction and use of his biography. It is therefore necessary to compare this re-reading with his biographical narration. Space was important to Mills's process of self construction and Texas, as one particular space of selfhood, in its real and imagined senses, shaped its meanings.

Mills narrated his own biography in the 'Letters to Tovarich'. These are recognized as autobiographical (Merrifield, 2001: 294; Mills and Mills, 2000: xiii) and in them Mills is at his most reflexive, saying on one occasion, 'I have never before written as I have written to you' (Mills and Mills, 2000: 315). He recognized in another passage that he was using Tovarich 'for ulterior purposes': 'I feel the need to say a few things about myself and so straighten out some points that are personal and hazy' (p. 222). By June 1960, there were 10 letters - about 90,000 words - collated in a manuscript entitled Contacting the Enemy intended for publication. To Miliband, he wrote that there was 'not a line of bullshit in it' (p. 191). Their autobiographical nature led Mills to write to his mother requesting information about his Texan roots so that he could explain to Tovarich 'who I am and how I got that way' (p. 326).

It is necessary to map the space within which Mills narrates his biography and that helps to shape it. Tovarich is a fictional intellectual living in the Soviet Union, and letters to him were written between 1956 and 1960, a political space marked by the Cold War, the most controversial period of Mills's career. He was then in middle age, full of frustrated ambition and restlessness in his career but aware of the persistent pull of New York. It is significant that the early letters were written during Mills's extended tour of Europe, when he was both physically and emotionally distant from the United States yet becoming aware - surprisingly - of its attraction. Others were written on a similar tour of Latin America. These cultural spaces encouraged confrontation with the bonds 
that tied him to his roots. But they were also written in a disciplinary space. He had by this time encountered the wrath of the profession and was becoming in mindset as much a 'free intellectual' as sociologist. He began writing pamphlets to engage the public as well as penning his most enduring contribution to sociology, The Sociological Imagination. This disciplinary space facilitated reflection on his position within sociology and how his biography impacted it. The spaces of its narration therefore set the autobiographical tenor of the Tovarich manuscript, encouraging Mills to make his own connections between his 'inner life' and work. In doing so he adopts a spatial approach by focusing on the lasting effect of Texas as the key space of his selfhood, coming to realize that simultaneously it fashioned both him and his vision of sociology. He recognized both authentic and idealized influences.

The Tovarich manuscript begins in the winter of 1956 in Copenhagen as a medium for the 'old American habit' of self-scrutiny (Mills and Mills, 2000: 222). In the sections written in Austria in the fall of 1957, Mills returns, in his mind at least, to Texas (pp. 24-30, 247-55), writing in dramatized terms about his grandfather's life as a murdered rancher (p. 25). But in later passages of the same part of the manuscript, Mills puts into Tovarich's mouth a question about what over-arching theme runs through Mills's biography to shape it, to which Mills answers more authentically about Texas. He makes reference to the lack of an extended family, the absence of intimacy within the home, the constant mobility preventing the planting of firm roots somewhere (the family home moved seven times) and the absence of intellectual or social capital (p. 27-9). The outcome of this upbringing, Mills admitted, was to reinforce the tendency toward Texan independence and self-reliance: 'I am as "self made" as it is possible to be ... I was cut off and alone ... out of all this came the search for, the demand for absolute autonomy' (p. 29). Answering his own question, Mills told Tovarich: 'the theme is clearly isolation. Its net result is the demand, the compulsion if you will, for autonomy. I don't like "alienation”. I am not, and never have been alienated. I mean just plain self-sought isolation' (p. 30).

In another part of the manuscript Mills directly connects his restlessness to the outlander mentality. 'What are the liabilities of such a biography? That you're very restless and you tend to make a fetish of energy [and] you're thrown back on yourself' (Mills and Mills, 2000: 249). 'It does not mean that I feel myself part of any intellectual community. I never have. I've always felt a sort of outlander in the East ... What this means is that I have been intellectually, politically, morally alone' (p. 250). The result of this, Mills admitted in a candid moment, was that:

for four or five years I have been pretty damned hard to deal with academically, for all I had to lean on against the trap of the academic world, was that old Wobbly feeling. So it was all poured into a furore of work. (p. 251)

Mills was not only made in Texas, he turned Texas into sociology.

It was turned into a particular kind of sociology, however. Mills's repositioning of sociology by means of the dissolution of the public-private distinction 
was rooted in the collapse of the public and private in his own life and work. Mills's narrative shows his awareness of this. He refers Tovarich to the mix of 'personal, political and professional factors' (Mills and Mills, 2000: 252) that determined his intellectual role and the work he did. His outlander's desire for the Wobbly's freedom and independence was not just for himself, for he tells Tovarich that 'he wants everyone else to be his own boss'. It is ordinary people for whom he writes. Mills tells Tovarich how he has responded to the public injustices in society and personal troubles in his life. It was to become radical, politically and personally, and to use his mind to make fate less unjust for others. Sociology, he explains to Tovarich, is about locating the biographical troubles of people with the 'very structure of a society' (p. 253). What is important Mills says, is not the details of his past 'although one should be aware of them', but 'how one interprets them, what rules for the present and the future one draws from them' (p. 253). In 1956, Mills had told Gerth to learn to 'use personal problems for intellectual purposes' (p. 201) and he repeated the advice to Tovarich when he said that writing was his way of dealing with his own personal troubles (p. 255). Mills's orientated his biography in a sociological direction therefore by translating his private troubles into public work.

This became the template for his repositioning of the discipline as a whole. He tells Tovarich that sociology should make as its core the translation of the personal troubles of others into public issues, an idea that culminates in The Sociological Imagination. The greater Mills's personal trouble, the more restless energy he had, the more voracious the sociological writing became, and the more convinced he was that sociology should reposition itself as the study of the same public-private intersection exemplified by his life and work. This imprints itself on Mills's description of the public role of intellectuals (see Mills and Mills, 2000: 276-81). The public intellectual, he tells Tovarich, links biography and social structure, private troubles and public issues, and must become 'obsessed' in devotion to this role. Tovarich is told that unfortunately the academy has abdicated this role in the United States. 'They relax into the private and everyday life of their milieu', but he built himself around projects 'that transcend the everyday and private'. 'As a writer, I have always tried to do just one thing: to define and dramatize the essential characteristics of our time' (p. 278). For the public intellectual, the private must lead to the public - to the social conditions and issues of the time - and back again. Mills tells his Russian friend that this has characterized his own writing:

the good writer tries to unite a variety of private lives with public affairs. He tries to enrich the private by making it publicly relevant. We ought to refuse to separate the two ... we cannot expect to solve the problems of private nor public life separately. (p. 280)

In saying this Mills is clearly aware that he made his own biography sociological and that these biographical experiences shaped his view about the proper purpose of the discipline. The reason why he is not alienated himself, he tells Tovarich (Mills and Mills, 2000: 281), is because he writes in order to 
translate private troubles into public issues; and the way to avoid ordinary people feeling alienated is for public intellectuals to translate their private troubles into public issues and thereby restore to them some control over human affairs. This is straight out of The Sociological Imagination, his manifesto for the discipline, and in one of the last parts of the manuscript he tells Tovarich that he would understand this dialogue better by reading it (p. 296). He had Texas on his mind when he wrote virtually the last entry in the notebook, entitled 'Self Images and Ambitions', for he located his sociological ambitions within this particular space of selfhood: 'I am a politician without a party, I am a writer without a cultural background and without much of the verbal sensibilities of "the born writer", I am a man who feels most truly alive only when working' (p. 303). And he soon worked himself to death.

\section{Conclusion}

Asked once why he wrote one of his major works Mills reports: 'my answer was that I was a Texan. He was puzzled and said that means cows and oil. And I said, of course, but also outlanders who came late in life to big cities and "discover them"' (Mills and Mills, 2000: 169). Mills's narrations of self thus make abundantly clear why the spatialization of his intellectual biography amounts to more than its Texanization. It is the contrast between the spaces of Mills's selfhood that is the best way to connect his life and work. His intellectual biography is normally approached temporally, with an emphasis either on his intellectual precursors or the socio-political context in which he wrote, but a spatial approach offers new insight into the connection between his 'inner life' and sociological writings. Texas as one particular space of selfhood, in its real and imaginary senses, is critical to unravelling this connection, but a spatial approach allows us to reclaim Texas's influence from its detractors and to see that its effects - positive and negative - worked only as a result of the mediation of subsequent spaces of Mills's selfhood.

In Cold War America - and in an equally chilly Columbia - Mills entered spaces of selfhood wherein Texas furnished him with an outlander mentality, a sense of autonomy, isolation and occupational aloofness that proved to be negative when he lived and worked in spaces of selfhood in the 'big cities', but was positive for his repositioning of sociology. The spatialization of his intellectual biography takes us toward his whole vision for sociology. The dominant portrayal of his Texan roots, whether by friends or foe, is that they were entirely unfortunate. This article has shown that by re-reading Mills's intellectual biography spatially we can see that Mills was not passive and used his Texan roots strategically in several ways, both personally and professionally. This space of selfhood was a socially constructed space, idealizations of which he used to excuse and sanitize his personal cantankerousness, to rationalize his public rejection, and to assist in his reformulation of sociology's public role. Texas was also authentic in its influences, assisting his repositioning of sociology as the 
study of the intersection between the public and private. In this regard, Mills turned his own personal troubles into sociology. They were rendered sociological in two ways: by means of his boundless, almost rabid energy that made him a voracious sociological writer; more importantly, by shaping his view that the public role of sociology was to facilitate ordinary people to make sense of the social condition by showing how their personal troubles both impacted on and were impacted by public issues. Mills's vision for sociology can be understood as an autobiographical comment on the collapse of the public-private binary in his own life. It has been argued that Mills's spaces of selfhood were critical to the process. The mediation between the authentic and idealized Texas of his upbringing and the effete culture of Mills's other spaces of selfhood, created the travails that he rendered into sociology and encouraged his repositioning of the discipline.

The utility of any new reading of Mills's intellectual biography depends upon what more it discloses. There are several advantages to a spatial approach. It allows Mills's own narration to assume significance, showing that he adopted several typifications in his narration of self, from Texan and 'outlander' to 'Wobbly'. It overcomes the simplistic presentation of Mills's Texan roots as entirely negative, allows us to locate Mills's repositioning of sociology in terms of his 'inner life', and overcomes the tendency to treat as dichotomous the public and private in Mills's intellectual biography by showing the way they interpenetrated each other in a recursive relationship both in his private life and public writings.

\section{Acknowledgements}

Work on this article was greatly facilitated by a visiting appointment in the Research School of Social Sciences at the Australian National University. The following colleagues read the article in draft and are excused its subsequent failings: Joe Bailey, Howard S. Becker, John Eldridge, Irving L. Horowitz and David Livingstone.

\section{Notes}

1 Because 'space' is both real and symbolic, it is different from 'context', which refers to actual places and milieux.

2 I owe to Howard S. Becker the insight that these two spaces of selfhood need to be distinguished, but their differences are not relevant for the purposes of the present argument.

3 Wakefield (2000: 9) reports an incident that displays Mills's artful use of an imagined Texas in reflecting upon his life and work. Mills told him of an incident in which a woman at a New York party said to Mills, 'I know you Mills - I read White Collar ... that's a story of a Texas boy who came to New York'. Mills paused, frowned, and then broke into a giant grin declaring with delight, 'and my God, she was right'. 


\section{References}

Anon (1906) Home Life with Herbert Spencer. Bristol: Arrowsmith.

Archer, M. (2000) Being Human. Cambridge: Cambridge University Press.

Bailey, J. (2000) 'Some Meanings of “The Private” in Sociological Thought', Sociology 34(3): 381-401.

Baldry, C. (1999) 'Space - The Final Frontier', Sociology 33(3): 535-53.

Becker, Howard S. (1994) 'Professional Sociology: The Case of C. Wright Mills', in

R. Rist (ed.) The Democratic Imagination. New Brunswick: Transaction Books.

Bell, C. and H. Newby (1977) Doing Sociological Research. London: Allen and Unwin.

Bendix, R. (1960) Max Weber. Garden City: Doubleday.

Binns, D. (1977) Beyond the Sociology of Conflict. London: Macmillan.

Boelen, W.A.M. (1992) 'Street Corner Society Revisited', Journal of Contemporary Ethnography 21: 11-51.

Brewer, J.D. (2004) 'Imagining The Sociological Imagination: The Biographical Context of a Sociological Classic', British Journal of Sociology 55(3): 317-33.

Butt, T. and D. Langdridge (2003) 'The Construction of the Self', Sociology 37(3): 477-93.

Casin, B.H. (1990) 'C. Wright Mills: Pessimistic Radical', Sociological Inquiry 60(4): 337-51.

Clecak, P. (1973) Radical Paradoxes. London: Harper Row.

Coser, L. (1971) Masters of Sociological Thought. New York: Harcourt Brace Jovanovich.

Coser, L. (1979) 'American Trends', in T. Bottomore and R. Nisbet (eds) A History of Sociological Analysis. London: Heinemann.

Coser, L. (1993) 'A Sociologist's Atypical Life', Annual Review of Sociology 19: $1-15$.

Denzin, N. (1990) 'The Sociological Imagination Revisited', Sociological Quarterly 31: 1-22.

Dowd, D. (1964) 'Thorsten Veblen and C. Wright Mills', in I. Horowitz The New Sociology: Essays in Social Science and Social Theory in Honor of C. Wright Mills. New York: Oxford University Press.

Eldridge, J. (1983) C. Wright Mills. London: Tavistock.

Fahey, T. (1995) 'Privacy and the Family: Conceptual and Empirical Reflections', Sociology 29(4): 687-702.

Form, W. (2001) 'Review of C. Wright Mills: Letters and Autobiographical Writings', Contemporary Sociology 40: 327-29.

Freeman, D. (1983) Margaret Mead and Samoa. Cambridge, MA: Harvard University Press.

Geertz, C. (1967) 'Under the Mosquito Net', New York Review of Books 14: September.

Geertz, C. (1983) Local Knowledge. New York: Basic Books.

Giddens, A. (1979) Central Problems in Social Theory. London: Macmillan.

Giddens, A. (1984) The Constitution of Society. Cambridge: Polity Press.

Gillam, R. (1975) 'C. Wright Mills and the Politics of Truth: The Power Elite Revisited', American Quarterly 27: 461-79. 
Gillam, R. (1981) 'White Collar from Start to Finish', Theory and Society 10(1): $1-30$.

Gregory, D. and J. Urry (1985) Social Relations and Spatial Structures. London: Macmillan.

Halsey, A.H. (1996) No Discouragement: An Autobiography. London: Macmillan.

Hearn, F. (1985) Reason and Freedom in Sociological Thought. London: Allen and Unwin.

Holmes, M. (2000) 'When is the Personal Political? The President's Penis and Other Stories', Sociology 34(2): 305-21.

Horowitz, I. (1962) 'The Sociological Imagination of C. Wright Mills: In Memoriam', American Journal of Sociology 68: 105-7.

Horowitz, I. (1963) 'Introduction', in I. Horowitz (ed.) Power, Politics and People: The Collected Essays of C. Wright Mills. New York: Oxford University Press.

Horowitz, I. (1964) The New Sociology: Essays in Social Science and Social Theory in Honor of C. Wright Mills. New York: Oxford University Press.

Horowitz, I. (1983) C. Wright Mills: An American Utopian. New York: Free Press.

Lechner, F. (1991) 'Simmel on Social Space', Theory Culture and Society 8(3): 195-201.

Lee-Treweek, G. and S. Linkogle (2000) Danger in the Field. London: Routledge.

Lipset, Seymour M. and N. Smelser (1961) 'Change and Controversy in Recent American Sociology', British Journal of Sociology 12: 41-51.

Livingstone, D. (2002) Science, Space and Hermeneutics. Heidelberg: University of Heidelberg Press.

Livingstone, D. (2003) Putting Science in its Place. Chicago, IL: Chicago University Press.

Lukes, S. (1972) Emile Durkheim. New York: Harper Row.

McCulloch, A. (1997) 'On the Public and the Private: A Comment on Fahey', Sociology 31(4): 733-9.

MacIntyre, A. (1984) After Virtue. Notre Dame: University of Notre Dame Press.

Mazlish, B. (1987) The Meaning of Karl Marx. New York: Oxford University Press.

Merrifield, A. (2001) 'An American Aboriginal: A Review of C. Wright Mills: Letters And Autobiographical Writings', Antipode 33(2): 290-6.

Miliband, R. (1964) 'Mills and Politics', in I. Horowitz The New Sociology: Essays in Social Science and Social Theory in Honor of C. Wright Mills. New York: Oxford University Press.

Miliband, R. (1968) 'C. Wright Mills', in G.W. Domhoff and H. Ballard C. Wright Mills and the Power Elite. Boston: Beacon Press.

Mills, Charles Wright (2000[1959]) The Sociological Imagination. Oxford: Oxford University Press.

Mills, K. and P. Mills (2000) C. Wright Mills: Letters and Autobiographical Writings. Berkeley: University of California Press.

Oakes, G. and A. Vidich (1999) Collaboration, Reputation and Ethics in American Academic Life. Urbana: University of Illinois Press.

Peel, J.D.Y. (1971) Herbert Spencer. London: Heinemann.

Ribbens-McCarthy, J. and R. Edwards (2001) 'Illuminating Meanings of "The Private", in Sociological Thought', Sociology 35(3): 765-77.

Ritzer, G. (2000[1983]) Sociological Theory, 5th edn. New York: McGraw Hill. Sack, R. (1980) Conceptions of Space in Social Thought. London: Macmillan.

Seidman, S. (1998) Contested Knowledge. Oxford: Blackwell. 
Sennett, R. (2002[1974]) The Fall of the Public Man. London: Penguin.

Shils, E. (1960) 'Imaginary Sociology', Encounter 14: 77-80.

Slater, D. (1998) 'Public-Private', in C. Jenks (ed.) Core Sociological Dichotomies. London: Sage.

Spain, D. (1992) Gendered Spaces. Chapel Hill: University of North Caroline Press. Spinrad, W. (1966) 'The Socio-political Orientation of C. Wright Mills', British Journal of Sociology 17: 46-59.

Taylor, C. (1989) Sources of the Self. Cambridge, MA: Harvard University Press.

Thompson, E.P. (1985) 'Remembering C. Wright Mills', in The Heavy Dancers. London: Merlin Press.

Tilly, C. (2000) 'Spaces of Contestation', Mobilisation 5: 135-59.

Tilman, R. (1984) C. Wright Mills: A Native Radical and His American Intellectual Roots. Philadelphia: Pennsylvania State University Press.

Tilman, R. (2003) Veblen, Dewey and Mills: An Intellectual Relationship. Lanham, MD: Rowman and Littlefield.

Turner, S.P. and J.H. Turner (1990) The Impossible Science. London: Sage.

Urry, J. (1981) The Anatomy of Capitalist Societies. London: Macmillan.

Urry, J. (2001) The Tourist Gaze, 2nd edn. London: Sage.

Wakefield, D. (2000) 'Introduction', in K. Mills and P. Mills C. Wright Mills: Letters and Autobiographical Writings. Berkeley: University of California Press.

Whyte, W.F. (1994) Participant Observer: An Autobiography. Ithaca, NY: Cornell University Press.

Young, R. (1987) 'Darwin and the Genre of Biography', in G. Levine (ed.) One Culture: Essays in Science and Literature. Madison: University of Wisconsin Press.

Young, R. (1988) 'Biography: The Basic Discipline for Human Science', Free Associations 11: 108-30.

\section{John D. Brewer}

\footnotetext{
Is Professor of Sociology at Aberdeen University, moving from Queen's University Belfast in July 2004. He has held visiting appointments at Yale University, St John's College Oxford, Corpus Christi College Cambridge and the Research School of Social Sciences at the Australian National University. He is a Fellow of the Royal Society of Arts, an Academician in the Academy of Social Sciences and a Member of the Royal Irish Academy, only the third sociologist to be elected in the Academy's 217-year history. He is Chair of the British Sociological Association and the author or co-author of 14 books. His latest research is on the sociology of peace processes.

Address: Department of Sociology, University of Aberdeen, Aberdeen AB24 3QY, UK. E-mail: j.brewer@abdn.ac.uk
} 


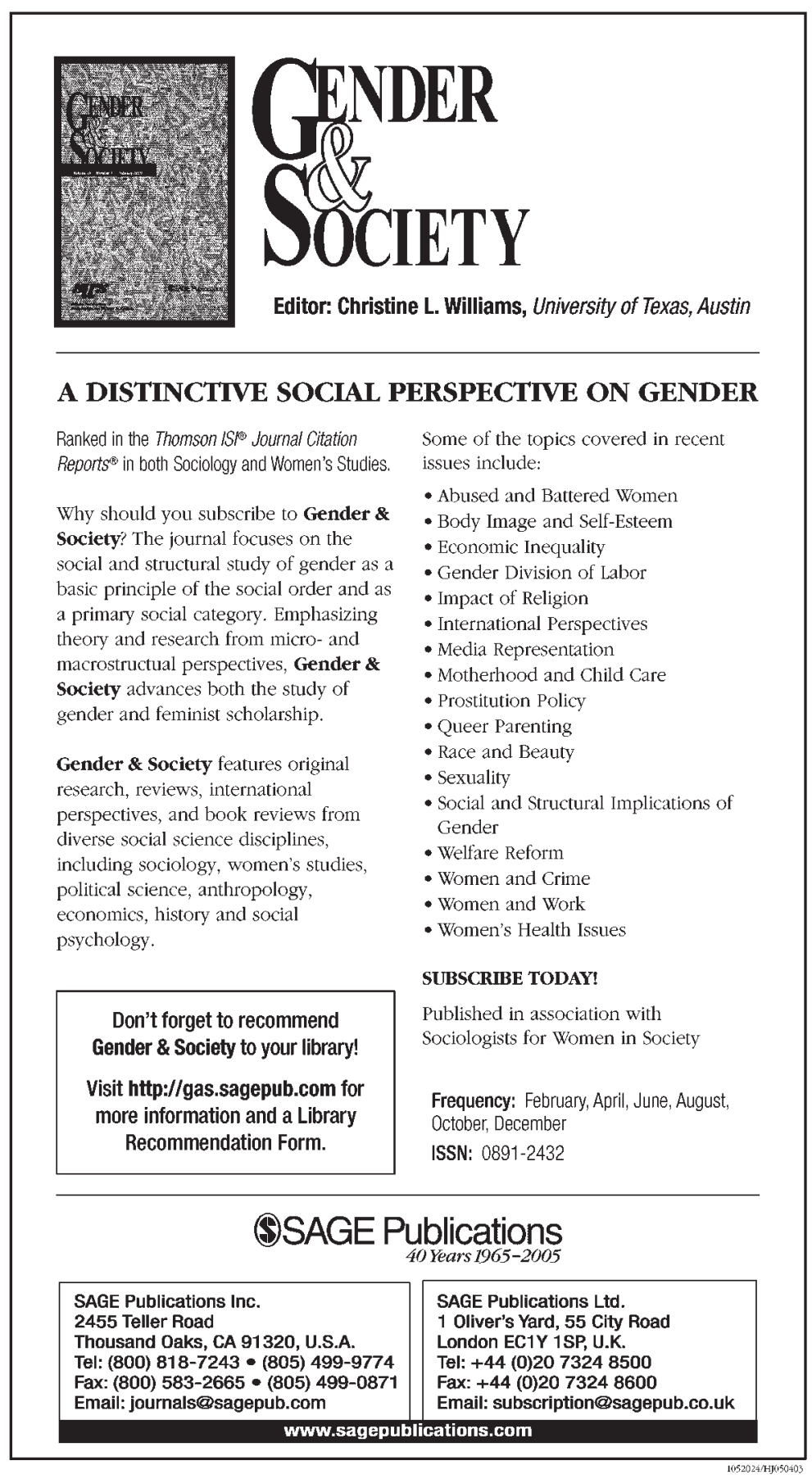

